\title{
Dos olhares sobre as memórias e novas construções de vida
}

Memórias de uma feminista.

PELIETIER, Madeleine.

Florianópolis: Mulheres, 2005. 80 p.

Nascida em 1874 em Paris, Madeleine Pelletier foi uma feminista bastante singular. Ainda criança, perdeu seu pai e foi criada com muita dificuldade por sua mãe. A primeira mulher francesa a passar nos exames para se tomar psiquiatra, Madeleine sempre lutou pela igualda de junto a os homens em tempos em que a mulher era tida, sem mais problemas, como um simples objeto de adomo. Pioneira na luta pelo aborto, não deixou de executar tal prática a inda que tenha sido repreendia diversas vezes, até ser internada em um asilo, onde morreu sozinha.

Zahidé Lupinacci Muzart, organizadora da publicação, contou com a ajuda de outras importantes estudiosas do feminismo para trazer a o público uma obra até então inédita, de uma autora que, ainda hoje, é muito pouco conhecida no Brasil. A própria organizadora só tomou conhecimento a partir dos estudos de Joan W. Scott, uma das principa is teóricas da história do gênero, responsável ta mbém pelo prefác io desta obra. A tradução foi feita por Paula Berinson, a partir de um manuscrito copiado de microfilme porJoana Maria Pedro, que faza a presentação do livro, diretamente do a rquivo da Bibliothèque Historique de la Ville de Paris.

$\mathrm{Na}$ mesma época em que escreveu as Memórias, Madeleine publicou um romance a uto biográfic 0 , porém escrito como fic ção, intitula do la femme vierge. Essa outra obra tinha um outro tom, era ma is explíc ita a o tratardos seus conflitos intemose da influência de certosfatose experiênciasna sua forma de pensar. No entanto, a inda que este outro lado, a té então inédito, tra te principalmente dos a contecimentos na "vida pública" de Madeleine Pelletier, esta obra traz deta lhes funda menta is, em sua composição, que não só expõem a vida da autora propriamente dita, mas ta mbém suas memórias, no sentido ma is parcial e pessoal do termo.

As memórias são a introdução à vida de Madeleine, sob a perspectiva de um momento muito particular. Já a o final de sua vida, faz uma espécie de retrospectiva de suas práticas e a tivida des liga das a os movimentos polític os e à sua luta pela emancipação das mulheres, a partir de uma hierarquia de fatos re-construíd os em uma cronologia um tanto diferente dos registros de que se tem conhecimento. É nesse sentido, principalmente, que o texto ganha um enorme valor biográfic 0 , na medida em que faz transparecer os conflitos, os idea is e os valores da autora.

Dra. Pelletier, como gostava de ser chamada, teve conta to com muitos dos diferentes grupos políticos da época. A partir dessa proximidade conseguiu tecer críticas bastante pertinentes a os diversos movimentos. Criticando os comunistas principalmente pelo seu a ntifeminismo, dizia: "[...] o partido é tudo menos feminista, sinto-o nas sessões. As poucas mulheres que figuram nas reuniões só lá estão porque a companham um homem" (p. 64). Ainda sobre as mulheres que freqüentavam o partido socialista, dizia que todas ainda estavam, de algum modo, muito presas a certos costumes e comportamentos exigidos da mulher na época, e isso se via, principalmente, na forma de se vestirem. Não era incomum para elas andarem inteiramente cobertas, inclusive suas faces, que pouco transpareciam a través de véus. 
Já entre os anarquistas o seu maior problema era com relação às críticas que rec ebia. Seu comportamento não era muito bem compreendido por eles. Mas, ainda que tivesse, por esse motivo, algum distanciamento, pôde perc eberatra vés de seus disc ursos que, porma is que fossem anti-clerica is, eram ainda permea dos por uma forte religiosidade. A revolução de que fala vam "[...] tinha a lgo de místic o [...]. No fundo, ainda que Louise Michel se dissesse atéia, a revolução era, para ela, uma espécie de justiça divina" (p. 35), e assim o era para a maioria dos a na rquistas.

Dentro do movimento feminista, especificamente, Madeleine encontrou uma atmosfera de mexericos, palavras da própria. Apontava, ainda, que em alguns momentos as reuniões mais pareciam encontros de velhas senhoras que, sem ter mais o que fazer, freqüentavam reuniões feministas, da mesma forma que freqüenta vam cursos na universida de, apenas para passar o tempo. Era bastante repreendida pelo movimento feminista toda vez que pensa va em a titudes ma is drásticas, e poucos a ceita vam o fato de ela se vestir como homem, a inda que só o fizesse em oca siões detemina das, já que tinha medo de, em seu consultório, perder os seus poucos pacientes.

No entanto, parecia ter adotado o figurino nem tanto para questionar as estétic as impostas a o corpo feminino, ou por causa de sua preferência sexual, já que dizia não ter inclina ção sexual alguma, mas muito mais para ser um homem, pois só os homens eram detentores de direitos. Seria, dessa forma, uma igual. Questionava todas as feministas que se importavam com o seu corpo e considerava corpo feminino quase como um fardo. Colocava toda a culpa de seus sofrimentos em serpobre e sermulher: "[...] tenho a infelic idade de sermulher e, a lém disso, não tenho um tostão" (p. 41).

Embora tenha trazido grandes conquistas às mulheres, a o que me parece, Madeleine Pelletier confundia seu desgosto pessoal com o mundo com a luta pela liberação delas. É lógico que não se pode ignorarque Madeleine se colocava à frente de seu tempo quando batia, por exemplo, com a questão da proibição do aborto. Eainda que os motivos não fossem talvezos ma is coerentes, a ruptura com os valores vigentes, a partir da estética que adotara, não pode ser deixada de lado.

Os conflitos e contra dições fazem parte da história de todo movimento e de cada uma das pessoasque oscompõem. Conhecerastrajetórias percorridas e as experiências vividas é fundamental para que se possam inventarnovos percursos e para que os movimentos não se tomem esta gna dos. A história da luta dasmulheres contra o assujeitamento é única, mas não homogênea, e é sempre interessante, e importante, conhecer as suas diversas faces.

Eliane Knom Pontifícia Universida de Católic a de São Paulo 